\title{
AGRIBUSINESS APPROACH AND DEVELOPMENT STRATEGY OF CORN (ZEA MAYS) TO MAINTAIN FOOD SECURITY IN KEDIRI REGENCY
}

\author{
Novi Haryati ${ }^{1, *}$, Arif Wahyu Setiawan ${ }^{2}$ \\ ${ }^{1}$ Department of Agricultural Social Economics, Faculty of Agriculture, University of Brawijaya, Indonesia \\ ${ }^{2}$ Department of Agricultural Social Economics, Faculty of Agriculture, University of Brawijaya, Indonesia
}

*corresponding author: noviharyati@ub.ac.id

\begin{abstract}
Corn has a strategic role in Indonesia because it has multipurpose functions such as as food, catle feed and industrial raw materials. The purpose of this study is to analyze: (1) base and non-base area of corn production in Kediri, (2) characteristic of corn farm management in Kediri, (3) the strategies to support food security in Kediri. Data used are primary data collected from farmers and also secondary data from the local government. Primary data was obtained through interviews of 30 respondents of farmers. Secondary data are collected from statistical bureau of Kediri Regency. The methods used are LQ and SWOT. The results show that the basic region of corn are Papar, Plemahan, Plosoklaten, Purwoasri and Pare. Farm management weaknesses in term of agribusiness activities are in the aspect of marketing and processing; however, supported sub-system in agribusiness has played important role in gaining benefit in the whole agribusiness system. According to SWOT analysis, farmers and government need to take advantages of the region strength to gain more opportunities. Improving more innovation on corn based-food production is also important to be induced more.
\end{abstract}

Keywords: corn production, agribusiness, SWOT, farm management

\section{INTRODUCTION}

Corn is one of agricultural commodities that have high economic value and potential for development and food security. National demand of corn is increasing year by year not only due to population growth, but also because of the growth of farm and food industry. Based on data from the Department of Agriculture, the needs of Corn continues to increase, especially for food industry and animal feed at an increasing rate of $3 \%$ and $5.78 \%$ per year, respectively (Kurniawan, 2008).

Corn production in 2010-2014 had increased. A total of 18.33 million tons of dry corn production in 2010 had significant increased to 19.13 million tons in 2014. However, the export has decreased from 44.514 tonnes to an average of 19.085 tonnes in 2014. This shows the increasing domestic demand of corn and the preference of corn for input domestically is also increasing. Even though, the total demand of corn is still higher than domestic production.

Overcoming the demand gap of corn, Indonesia uses import as the major solution. The import value of corn is very high, which is 772,663 tons
(Direktorat Jenderal Tanaman Pangan, 2015). Therefore, corn production in Indonesia has high opportunity to be developed more in order to fulfill gap in corn demand.

Kediri is one of corn producer region in East Java, Indonesia. However, this region has faced some obstacles regarding downstream industry of corn. It was because the development of corn downstream industry is not conducted based on the region where the main corn producer existed. Moreover, the industry is also fulfilling corn as its input from other regions such as Nganjuk Regency dan Mojokerto Regency (Rahayu and Nevastara, 2012). This is the tipical problem of agribusiness in Indonesia since the corn producers are small-scale farmers and the locations are seperated in the different regions.

The linkages of agribusiness are also another problem. The weaknesses of this aspect are regarding the coordination problems among subsystem in agribusiness and not equally bargaining position among the agents in the agribusiness subsystem. Farming or production system is the weakness in the sub-system that the existence of 
government in reducing the problems is definitely needed.

The next interesting point is having understanding of development strategy for corn farm management in Kediri in order to stenghten agribusiness system and food security as well.

The purpose of this research is to analyze basic and non-basic region of corn production in Kediri, to observe more regarding agribusiness system existed in Kediri for corn commodity.

\section{RESEARCH METHODS}

Research is conducted in Kediri Regency based on purposive method. It is a descriptive-analysis study that based on finding descriptions about problems or phenomena objectively (Sukmadinata, 2011). This research used primary and secondary data. Data of corn production was derived from Statistical Bureau of Kediri Regency from 2009 to 2014, while primary data was collected from interview with 30 respondents whose are leaders of group farmers. The interview was conducted during agricultural extension held by Food Security and Agriculture Extension Bureau of Kediri on December, 2014.

Location Quotien Analysis was used to solve the first problem. According to Hendayana (2003), the using of LQ is not only for economic purposes but also determining commodity spreading and to identify potency of the region in term of agribusiness production potency as it has been applied by Research and Development Center of Crop (Puslitbangtan) that has discussed soybean commodity system. Quantitative data used are production of corn and all crops (Rahayu, 2012). This analysis used two assumptions. Firstly there is homogenous demand pattern in society which means demand in research region is the same with national demand. Secondly, Production of corn is firstly used to fulfil the region's own need and the rest is for other region's need. The formula is:

$$
L Q_{i}=\frac{v_{i} / v_{t}}{V_{i} / V_{t}}
$$

Note:

LQi = Location Quotient of corn in a sub district

$\mathrm{vi}=$ corn production in sub district $-\mathrm{i} ; \quad \mathrm{Vi}=$ total production of crops in subdistrict $\mathrm{i}$

$\mathrm{vt}=$ corn production in Kediri Regency; $\mathrm{Vt}=$ total production of crops in Kediri Regency

Decision Making Criteria:

LQ >1; sub-region-i is considered as corn production basic area in Kediri Regency.

LQ $<1$; sub-region $-\mathrm{i}$ is considered as non-basic area of corn production in Kediri Regency
$L Q_{s}=1$; sub-region-i is considerd as production basic area in Kediri Regency but it can only enough to supply the needs of its own territory.

Agribusiness Approach is using to solve second problem. According to Garcia (2005) It is the coordinating science of supplying agricultural production inputs and subsequently producing, processing and distributing food and fibre.

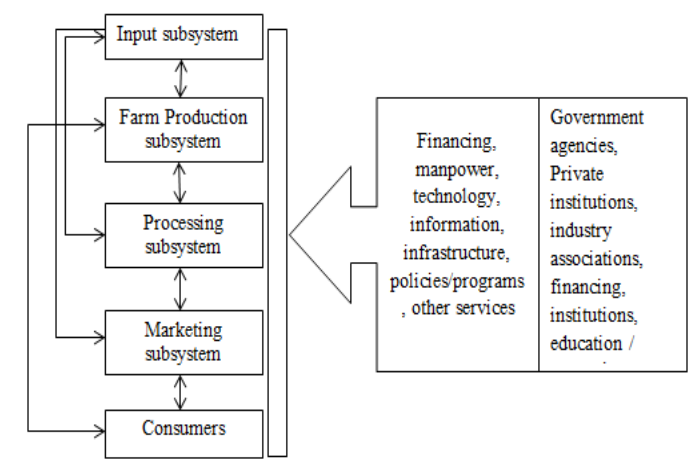

Figure 1. Agribusiness Concept (Garcia, 2005)

Agribusiness concept is market oriented. This means that the components must function in a way that will lead to the satisfaction of consumers' need. Third problem will be solved by SWOT Analysis. SWOT is strategic planning tool consists of elements such as strength, weakness, opportunity, and threat. It is done by determining each elements including the weight and rating. The next step is counting the total score of every elements to determine the best strategy (Rangkuti, 2006).

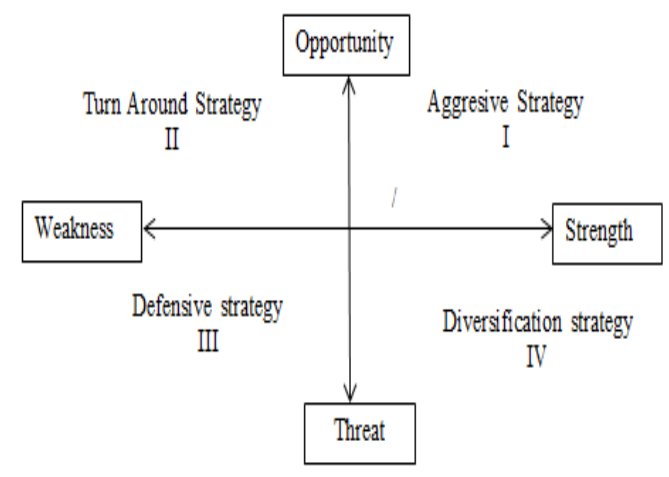

Figure 2. SWOT Analysis (Rangkuti, 2006)

\section{RESULTS AND DISCUSSION}

\section{Basic and Non-Basic Area}

LQ Analysis is conducted by comparing corn production per sub district with the total production. Research shows that there are 13 basic sub-regions of corn production (LQ > 1), it means that the sub regions are having more than enough production of corn. The basis area are Puncu, Pagu, Papar, Plemahan, Plosoklaten, Kayenkidul, Gurah, Pare, 
Ringinrejo, Ngadiluwih, Kras, Ngancar, dan Kunjang as mentioned in Figure 3.

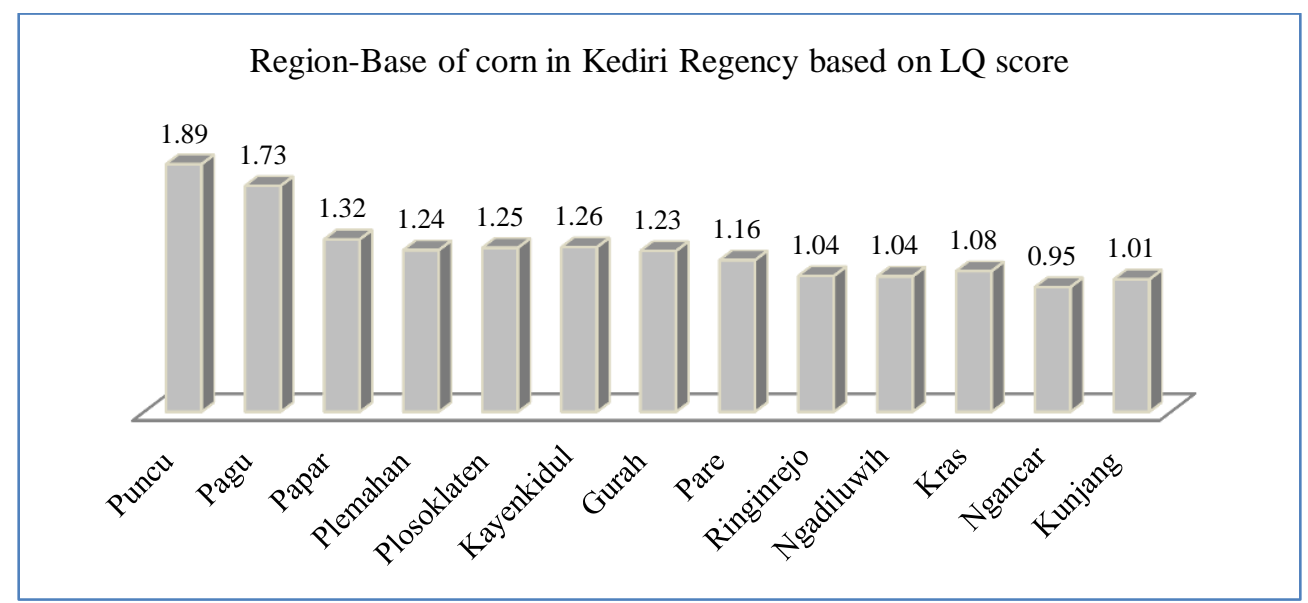

Figure 3. Region-Based of corn in Kediri Regency based on LQ score

The thirtieth region shows the highest score is 1.89 (Puncu), 1.73 (Pagu) and 1.32 (Papar). Average production can be seen in Table 1. The highest production of corn the lowest LQ value it has because the counting of LQ is included other crops that have fluctuation in term of production.

Table 1. Highest LQ score and its production average of corn in Kediri Regency

\begin{tabular}{llcc}
\hline No & Sub-Districs & $\begin{array}{c}\text { LQ } \\
\text { Score }\end{array}$ & $\begin{array}{c}\text { Production } \\
\text { Average } \\
\text { (quintal) }\end{array}$ \\
\hline 1 & Puncu & 1.89 & 135.242 \\
2 & Pagu & 1.73 & 135.710 \\
3 & Papar & 1.32 & 221.239 \\
4 & Plemahan & 1.24 & 263.776 \\
5 & Plosoklaten & 1.25 & 201.078 \\
\hline
\end{tabular}

Source: Statistics of Kediri analyzed

\section{AGRIBUSINESS SYSTEM}

Most respondents are farmers, aged between 35 to 60 years old. Their main occupation is in agriculture with a sideline of having kiosks, working as pedicab drivers, and civil servants. During planting season, mostly farmers cultivated corn around 2 to 3 times. Corn farmers majority are the owner of the land and the rest is sharecroppers and labor.

\section{Input sub-system}

Main inputs required are seeds, fertilizers, and pesticides. Seeds are purchased at agriculture shop or Kiosk $(97 \%)$ and the rest $(3 \%)$ were taken from the previous harvest. It is not difficult to find kiosk in Papar. Farmers believed that seeds they bought from shop is qualified and certified than from previous plan. This is why only least of them use seedling from previous plant. Type of fertilizer used by farmers are mostly chemical fertilizers $(82 \%)$ and the rest is natural fertilizers, for example compost, manure, and green manure (Figure 4). To prevent from weeds, virus or diseases, By majority of farmers used pesticides (93\%) while the rest (7\%) did not use pesticides. 


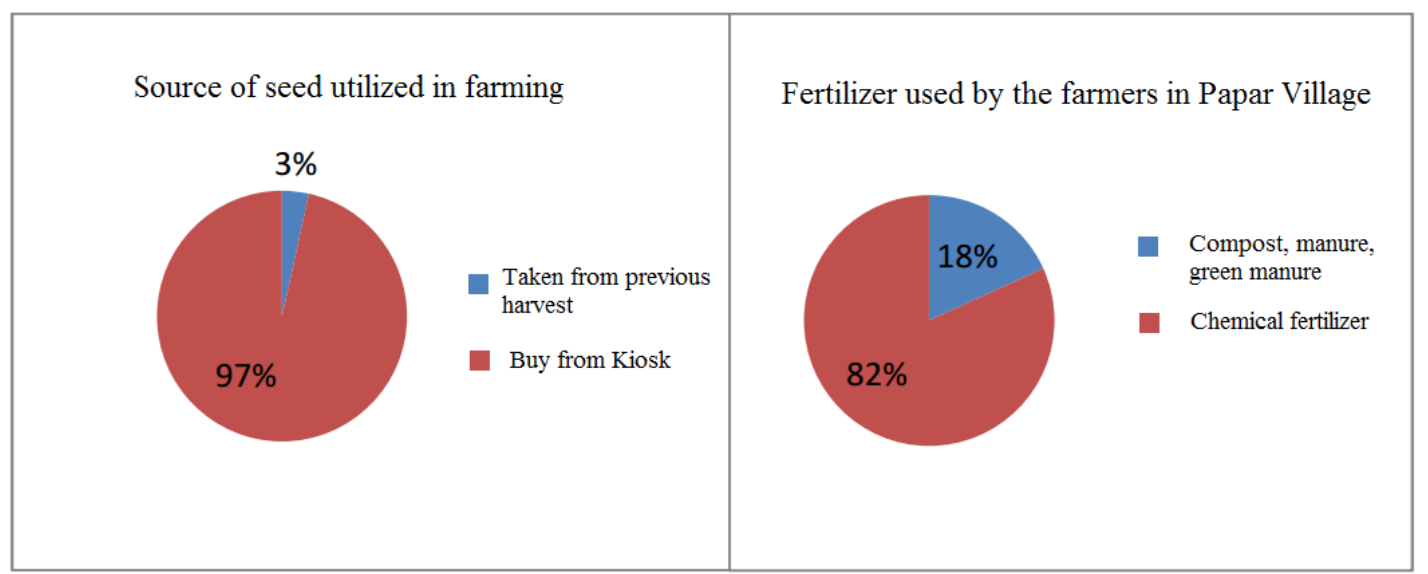

Figure 4. Source of Seedling and Types of Fertilizers used by Corn Farmers

\section{Farm Production Subsystem}

It consists of all individuals and entreprises engaged in the production and propagation of animals and animal products, plant products, forests products, and even aquatic products for direct consumption and/or as intermediate products for processing. Most of farmers are working on other people's land (66\%) and on their own (34\%) under the agreement with the land owners. Most of farmers calculate their cost in every year(63\%) and the rest of them $(37 \%)$ calculate their cost per planting season. The next problem is the cost increasing as shown in Figure 5.

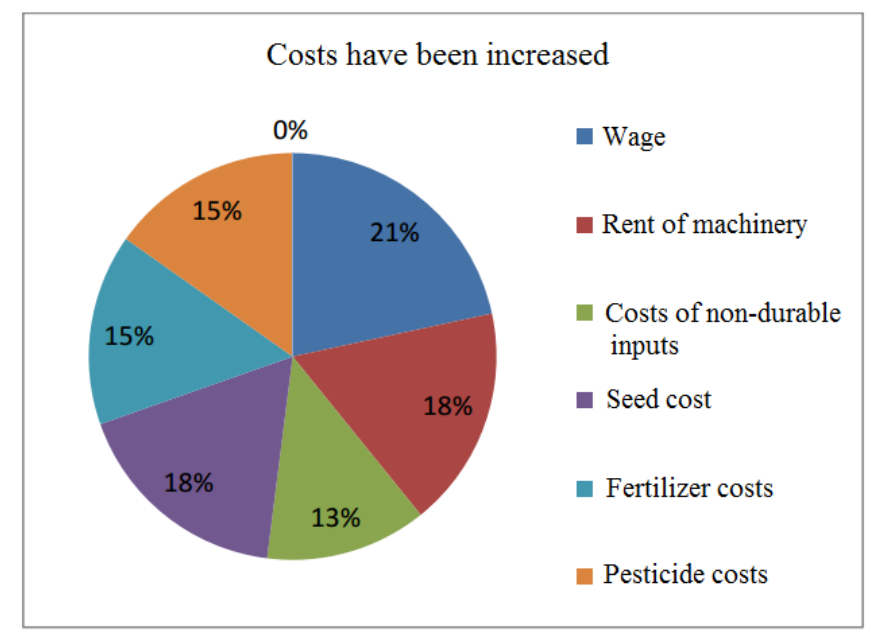

Figure 5. Increasing cost in corn farm management

Fluctuation in term of cost that happened are wage costs, heavy equipment rental costs, the cost of non-durable supplies, the cost of seeds, fertilizer, and pesticides. Those costs cause reducing the profit of corn production.

Production of corn has many technical problem in the study area. The factors causing the failure of corn production are pests, natural disaster, others. The graph is represented below.

Regarding the marketing of corn commodity, there are $83 \%$ of responden giving opinion that there is difficulty to access corn market. This is also the common problem faced by agriculture market. 


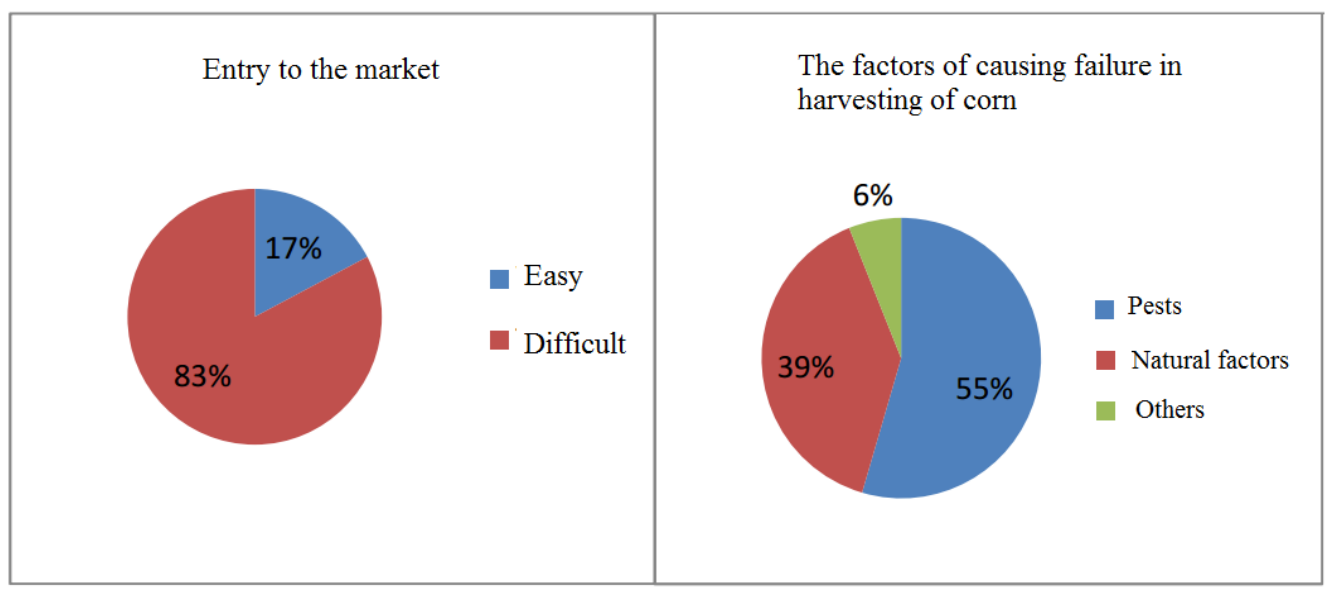

Figure 6. The perception of respondents on corn market and factor affecting corn production

\section{Processing sub-system}

After harvesting was done, agricultural products need to be store in a storage room. This is one of the processes undertaken to prepare yields before being sold to the market. Most farmers in Kediri Regency store their yields by join together with other farmer who has storage room in their house $(67 \%)$ and the rest of them rented warehouses $(33 \%)$. Not all farmers conduct miling process either wet and dry. Total of $83 \%$ corn farmers grind their yield and $17 \%$ of them did not perform milling. Most of the farmers hired milling machine $(78 \%)$ because they do not have it while $22 \%$ farmers joined their neighbors miling machines. All respondents belive that the processing units are not yet available in Kediri.

In Kediri, corn is used as raw material for small and medium industries. According to Department of Cooperatives, Industry and Trade Kediri, the number of small and medium industries and corn processing until December 2012 has only reached 25 industries (BPS, 2012).

\section{Marketing sub-system}

Farmers prefer to sell their crops in the form of corn package, while $30 \%$ use corn for everyday needs (self-consumption) and the remaining $8 \%$ is used as seeds. $63 \%$ of yield are harvested and store to the warehouse, while $30 \%$ are sold while still in the land and $7 \%$ are sold to the market as mentioned in Figure 7. Means of Transportation used was a pick up car or truck that are mostly used by farmers to bring farm product from the mill to the house (warehouse) or $85 \%$. In addition, means of transportation used to carry farm product from the house (warehouse) to market (11\% and $4 \%$ ). The farmers do not use the means of transportation to bring agricultural product to the house, mills, and the market.

Risk is a condition that can not be predicted by farmers. Most farmers (83\%) thinks that they had difficulty in finding a buyer in the Corn Market, while the remaining $17 \%$ felt easier to find buyers in the corn market. because they partnered with Bisi Company. Factors leading to failure in harvesting is pest $(55 \%)$, natural factors $(39 \%)$, and others $(6 \%)$. Another problem is the difficulty in getting the warehouse, so that $75 \%$ of them sell the yeald at market prices, $12 \%$ sells below market prices, while $13 \%$ of farmers are confident to sell above the market price. 


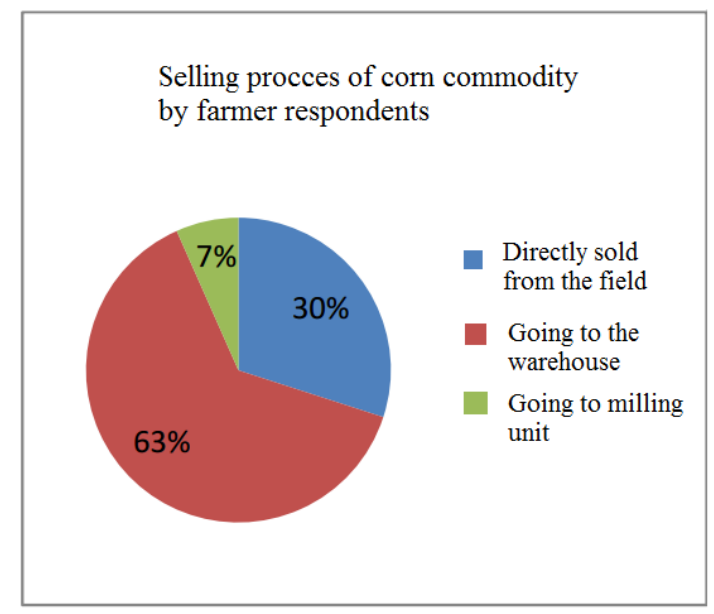

Figure 7. Source of Capital in Corn Farming

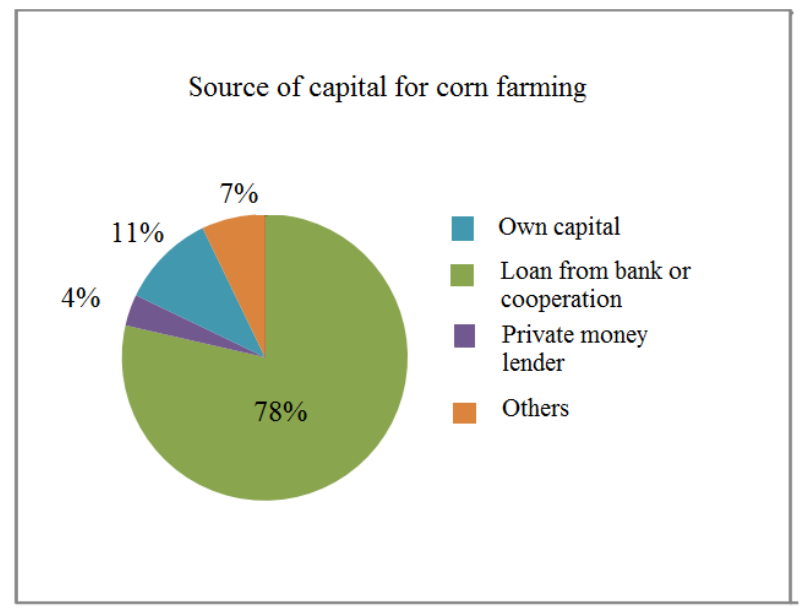

Figure 8. Source of capital for corn farming

\section{Supporting sub-system}

Most of the farmers commontly borrow bank, BMT or local cooperatives to finance their farm management which is 78\%. Farmers sometimes prefer to take collective loan under the group farmer and also individual loan (Figure 7).

Among those sources of capital, there is $4 \%$ the capita or cost of farming coming from private money lender. The problem of borrowing private money lender is the return of the capital usually in high rate. However, the transaction cost of this alternative is relatively low; therefore, farmers possibly still choose this option in order to save their farming

production and other condition that push them to take this option; even though, the probability of having loss due to the capital cost is also high. Formal bank on the other hand is elatively save to borrow but in term of transaction cost is relatively high for small scale farmers.

\section{SWOT analysis}

SWOT analysis is done by first determining each factors and giving rating and weight based on the internal and external factor of corn farming in Papar Distric, Kediri Regency. From the analysis, the results can be descrived in Table 2 and 3 .

Table 2. Strength and Weakness Factors of Corn Farm Management in Kediri Regency

\begin{tabular}{clccc}
\hline \multicolumn{1}{c}{ Strength } & $\mathrm{W}$ & $\mathrm{R}$ & $\mathrm{W} \times \mathrm{R}$ \\
\hline 1 & Most of people put farming as their way of living & 0.12 & 4 & 0.48 \\
2. & Corn as the main crop of Kediri Regency & 0.03 & 2 & 0.06 \\
3. & Productivity of corn is increasing from year to year & 0.09 & 3 & 0.27 \\
4. & Motivation and enthusiasm of farmers for corn farming in Kediri is very good & 0.04 & 2 & 0.08 \\
& because it has become a habit or culture of the society. & 0.12 & 3 & 0.36 \\
5. & Agroclimate condition that best suit the corn farming in Kediri Regency & 0.14 & 4 & 0.56 \\
6. & Government support is high & 18 & 1.81 \\
\hline & & Total & $\mathrm{R}$ & $\mathrm{W} \times \mathrm{R}$ \\
\hline & & 0.03 & 2 & 0.06 \\
\hline 1 & Limited presence of agricultural institution & 0.09 & 2 & 0.18 \\
2 & Marketing product is still in the form of raw materials & 0.06 & 4 & 0.24 \\
3 & Unstable price of corn & 0.13 & 3 & 0.39 \\
4 & Limited marketing of processed product & 0.03 & 1 & 0.03 \\
5 & Less active of group farmers in Kediri Regency & 5 & 1.26 \\
\hline
\end{tabular}


Table 3. Opportunity and Threat Factors of Corn Farm Management in Kediri Regency

\begin{tabular}{|c|c|c|c|c|}
\hline & Opportunity & $\mathrm{W}$ & $\mathrm{R}$ & W $\times$ R \\
\hline 1 & $\begin{array}{l}\text { Expansion opportunities of dry land and utilization of } \\
\text { vacant land are still open }\end{array}$ & 0,08 & 4 & 0,32 \\
\hline 2 & Local and national corn demand continues to increase. & 0,07 & 3 & 0,21 \\
\hline 3 & Development of information and technology & 0,16 & 4 & 0,64 \\
\hline 4 & $\begin{array}{l}\text { The using of corn as subtitute of rice, especially for people } \\
\text { who avoid some diseases such as diabetes }\end{array}$ & 0,06 & 1 & 0,06 \\
\hline 5 & $\begin{array}{l}\text { Higher and higher growth of supermarket as a place to sell } \\
\text { corn }\end{array}$ & 0,14 & 3 & 0,42 \\
\hline \multirow[t]{3}{*}{6} & $\begin{array}{l}\text { The growth of mass communication that can help spreading } \\
\text { information technology of conducting farm business }\end{array}$ & 0,03 & 2 & 0,06 \\
\hline & Total & & 17 & 1,71 \\
\hline & Threat & $\mathrm{W}$ & $\mathrm{R}$ & W $x$ R \\
\hline 1 & Increasing import of processed product based on corn & 0,13 & 3 & 0,39 \\
\hline 2 & The used as new technology in seed as basis of GMO & 0,08 & 3 & 0,24 \\
\hline 3 & Free market policy especially related to AEC & 0,11 & 4 & 0,44 \\
\hline 4 & Fluctuation in term of corn price & 0,03 & 2 & 0,06 \\
\hline 5 & Land using as housing complex & 0,08 & 1 & 0,08 \\
\hline 6. & Land degradation & 0,03 & 1 & 0,03 \\
\hline \multicolumn{3}{|c|}{ Total } & 14 & 1,24 \\
\hline
\end{tabular}

Note: $\mathrm{W}=$ weight, $\mathrm{R}=$ rating

Figure 8 describes the best strategy to improve agribusiness system of corn in Kediri Regency. The difference between strength and weakness is 0,55 while opportunity and treath is 0,47 . It is located in the first quadrant, so the best strategy is Aggresive Strategy (Strength-Opportunity Strategy. Policy makers must be conducted to maintain the increased land area, harvested area, production and productivity of maize commodities.
Beside that, it is also important to use technology and communication to create innovative new products. Building information system of pricing and open access market that can help farmers and improving more innovation and technology on corn based-food production is also important to be carried out.

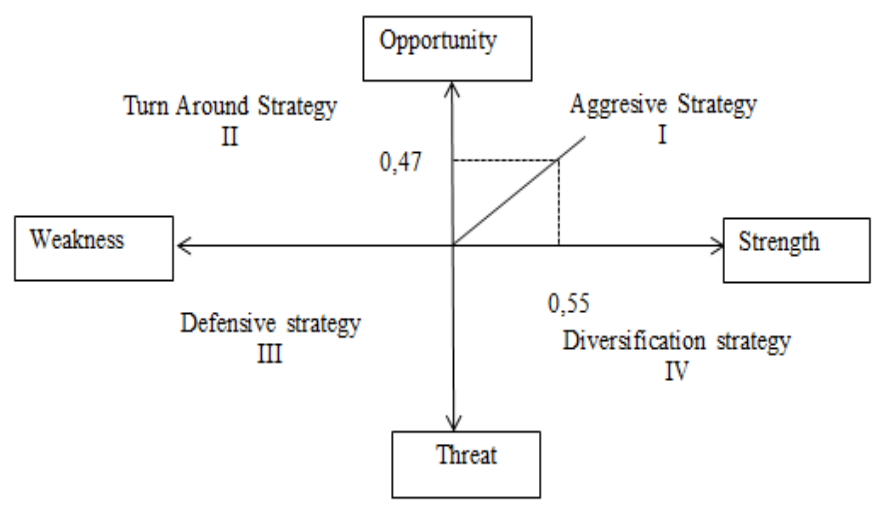

Figure 9. SWOT Quadrants, SO Strategy 


\section{CONCLUSION}

1. Basic sectors of Corn Production in Kediri Regency are Puncu, Pagu, Papar, Plemahan, Plosoklaten, Kayenkidul, Gurah, Pare, Ringinrejo, Ngadiluwih, Kras, Ngancar, Kunjang, because it has LQ more than 1 .

2. Thirteen from twenty-five regions are considered as basic sub-regions, which are able to fulfill their needs in corn (self-sufficiency).

3. Agribusiness System of Corn in Kediri Regency is characterized by lack of marketing and processing sub-systems.

4. Farmers sell their product mostly in term of raw materials, while the number of processing sectors in term of small and medium entreprises are limited. That is why their product are always be sold below market price due to the problem of getting information in the corn market (barrier to entry corn market).

5. Government and private sectors has already support in term of capital and technical support during planting season. Therefore, Aggressive Strategy (Strength-Opportunity Strategy) needs to be conducted.

\section{REFERENCES}

Badan Pusat Statistik Kabupaten Kediri. (2012). Kediri dalam Angka: Industri dan Perdagangan. 16-20.

Direktorat Jenderal Tanaman Pangan Kementrian Pertanian. (2015). Rencana Strategis
Direktorat Jenderal Tanaman Pangan Tahun 2015 - 2019. 15-18.

Garcia, P.G. 2005. Agribusiness Management: System Approach. Philippines: Southeast Asian Regional Center for Graduate Study and Research in Agriculture (SEARCA). 2035.

Hendayana, R. (2003). Aplikasi Metode Location Quotient (LQ) dalam Penentuan Komoditas Unggulan Nasional: Jurnal Informatika Pertanian Volume 12 Tahun 2003. 1-4.

Kurniawan, A.Y., Hartoyo, S., \& Y. Syaukat. (2011). Analisis Efisiensi Ekonomi dan Daya Saing Jagung pada lahan Kering di Kabupaten Tanah Laut Kalimantan Selatan: Jurnal Forum Pascasarjana Vol. 31 No. 2 April 2008. 93-103.

Rahayu, P \& Navastara, A. M. (2012), Penentuan Wilayah Potensial Komoditas Jagung di Kabupaten Kediri, Jurnal Teknik Pomits 2014. 1-2.

Rangkuti, J. (2006). Analisis SWOT: Teknik Membedah Kasus Bisnis Reorientasi Konsep Perencanaan Strategis untuk menghadapi Abad 21. 57-59.

Sukmadinata, N. S. (2011). Metode Penelitian Pendidikan Pendekatan Kuantitatif, Kualitatif dan R\&D. Cetakan 11. 23-26. 